\title{
Technological Capability Analysis of Competitor Using Patent Information: Focused on Mobile Communication Technology development companies
}

\author{
Seung-Wook Choi ${ }^{*}$ Chang-Won Lee ${ }^{* *}$, Yen-Yoo You ${ }^{* * *}$ \\ Doctoral Student, Dept. Of Knowledge Service \& Consulting, Hansung University ${ }^{*}$ \\ Professor, Dept. Of Public Administration, Hansung University ${ }^{* * *}$ \\ Professor, Dept. Of Knowledge Service \& Consulting, Hansung University ${ }^{* * *}$ \\ 특허정보를 이용한 경쟁기업의 기술역량 분석: 이동통신
기술개발 기업을 중심으로 \\ 최승욱, 이창원 ${ }^{* *}$, 유연우 ${ }^{* * *}$ \\ 한성대학교 지식서비스\&컨설팅학과 박사과정*, 한성대학교 행정학과 교수 ${ }^{*}$, \\ 한성대학교 지식서비스\&컨설팅학과 교수
}

\begin{abstract}
Patent information analysis has been carried out for technological capability analysis of competitors relating to next generation mobile communication. Various analysis methods, such as applicant analysis, technology classification analysis, indicator analysis and the like have been utilized as a method of analyzing patent information. As a first step for the technological capability analysis of competitors, applicants having high patent activity(PA) were selected, and as a second step therefor, technology classifications showing high technological independence (TI) were selected. Furthermore, portfolios for technology classifications showing high technological independence in the patents of main applicants having high patent activity by matching results the first and second steps together were prepared. Through such a process, portfolios for important technologies which have been concentrically researched by competitors could be analyzed. Accordingly, the present analysis results will help to carry out strategic R\&D management, such as the establishment of company R\&D plans and patent strategies.
\end{abstract}

Key Words : Mobile Communication, Patent Information Analysis, Patent Indicators, Technological Capability Analysis, Technology Portfolio

요 약 차세대 이동통신 관련 경쟁기업의 기술적 역량분석을 위해 특허정보 분석을 실시하였다. 특허정보의 분석 방법으로는 출원인 분석, 기술분류 분석, 지표분석 등 여러 분석방법을 활용하였다. 경쟁기업의 기술적 역량분석 1 단 계로 특허활동도(Patent Activity:PA)가 높은 출원인을 선별하였고, 2단계로 기술자립도(Technological Independence:TI) 가 높은 기술분류를 선별하였다. 그리고 1 단계와 2 단계 결과를 매칭하여 특허활동도가 높은 주요 출원인 중에서 기술 자립도가 높은 기술분류에 대한 포트폴리오를 작성하였다. 이와 같은 과정을 통해 경쟁기업간에 집중적으로 연구되고 있는 중요 기술 포트폴리오를 분석할 수 있다. 이 분석 결과는 기업의 R\&D계획, 특허전략 수립 등 전략적 $\mathrm{R} \& \mathrm{D}$ 관 리 수행을 돕는 역할을 할 것이다.

주제어 : 이동통신, 특허정보 분석, 특허지표, 기술적 역량 분석, 기술 포트폴리오

\footnotetext{
* This research was financially supported by Hansung University.

Received 21 March 2014, Revised 20 April 2014

Accepted 20 May 2014

Corresponding Author: Yen-Yoo You(Hansung University)

Email: threey0818@hansung.ac.kr

(C) The Society of Digital Policy \& Management. All rights reserved. This is an open-access article distributed under the terms of the Creative Commons Attribution Non-Commercial License (http://creativecommons.org/licenses/by-nc/3.0), which permits unrestricted non-commercial use, distribution, and reproduction in any medium, provided the original work is 


\section{Introduction}

Recently, in the globally competitive environment, patent information has performed an important role in defining company strategies and R\&D decision-making[1]. Patent information has been recognized as an abundant potential resource for innovation and technological change until now[5]. Furthermore, patent information has become an important resource as competitive information which enables companies to secure strategic superiority[13].

Also, in order to evaluate the future advancement possibility of a technology and determine whether or not to make an investment, a method of observing the advancement of technologies using patent-based indicators was used as a method of understanding the current state of a technology life cycle (TLC)[8].

In this study, the technology classification presented in the Korean Industrial Technology Road Map 2011 made by the Korea Institute for Advancement of Technology (KIAT) was referred to for the classification of a next generation mobile communication technology utilized for the technological capability analysis of companies[9].

The patent information utilized for the analysis can be easily accessed and searched by any person with regard to recent technologies for which patent applications have been filed in each country[3], and a patent database for the patent information enables statistics for analyzing search results to be easily produced. Also, the patent database has been utilized as objective data because it enables a systematic data search to be performed, and R\&D activities through the filing of patent applications are published through the publication of the patent applications via the Korean Intellectual Property Office (KIPO). Many parts of technology information are included in patents, and various existing researches for the utilization of patents as a means for $R \& D$ activities were investigated[7].

The patent information used in the method of analyzing the technological capabilities of individual companies is based on the US patent database including information on patents filed in the field of next generation mobile communication. The analysis was carried out step by step, and patent applicant analysis, technology classification analysis, patent indicator analysis and the like were performed.

Consequently, a first object of the technology capability analysis of companies is to provide a methodology for discovering the portfolios of concentrated research technologies of relevant companies regarding mobile communication technologies. A second object thereof is to help relevant companies perform their strategic R\&D management better based on results of the technological capability analysis.

\section{Theoretical Background}

DAIM et al.[3] explained that patent analysis is an important method of using patent data for extracting information regarding a specific industry or technology. Furthermore, they stated that patent data can be easily accessed in most countries and guidelines for the use of keywords and classification are provided.

ERNST[7] introduced the types of a patent portfolio for a strategic R\&D project while stating that the benchmarking of companies to competitors regarding patent strategy establishment and general technology quality has been increasing. That is, ERNST defined five patent indicators for a patent activity and patent quality, namely, patent applications, the share of granted patents, the share of valid patents, the share of US patents, and a citation ratio. In addition to this, ERNST also defined patent quality and a patent activity indicator.

Meanwhile, ERNST[6] stated that patent information is used for the monitoring of competitors, technology valuation, R\&D portfolio management and the like as 
means for mergers and acquisitions, and the human resource management of companies. Also, ERNST explained that reviewing a frame work for the use of patent information in view of technology management, it internally supports the making of R\&D investment decisions and effectively protects companies from imitated products, and that it also externally functions to discriminate and evaluate information for technology creation and to support patent portfolio strategies and operation.

WILSON[16] stated that patent analysis can help to make decisions on scope, such as enterprise take-over, sale, $R \& D$ programs, the development of new products and the like. XU[17] explained that IP (Intellectual property) accounts for a considerable part for company profits in the industrial field, and technology, business and legal information are important for the development, protection and commercialization of IP.

TSENG et al.[15] stated that patent indicators are utilized for strategic technology management, the evaluation of competitive positions and the like. Furthermore, they explained that an indicator for technical strategies (citation, science linkage etc.) and an indicator for valuation (family size, the Number of claims, Patenting strategy, Legal disputes, etc.) of contents of the patent indicators are influenced by each other.

CHIU et al.[2] stated that the valuation of a patent is intended so that a company can correctly check the value of the patent and can make business decisions objectively. Furthermore, the indicator of patent values and the scientific-based indicator of patent quality and the like were reviewed. ZHENG et al. [18]. stated that the counting of patents and citations is mainly used for the appraisal of technical innovation. Furthermore, they stated that the counting of international cooperative patents is a methodological issue now that international cooperation has been increasing. TRAPPEY et al[14] performed research for the patent quality analysis of companies and stated that the companies can customize products and determine innovative product development through the patent quality analysis.

\section{Analysis of Patent information in the Field of Mobile Communication Technology}

A technology targeted for patent information analysis was based on technology classification in the field of next generation mobile communication presented in the Korean Industrial Technology Road Map 2011.

Total investigated patents were based on 16,926 US patents searched through the Worldwide Intellectual Property Service (WIPS) which is a patent search database. All the patents were collected through keyword searches for each technology classification. The scope of the searched patents covers patents filed between from 1995 to 2011.

Table 1 below shows the technology classification in the field of next generation mobile communication, and the technology classification is divided into three big classifications and eight medium classifications.

〈Table 1〉 Next Generation Mobile Communication Technology Classification

\begin{tabular}{|c|c|c|}
\hline $\begin{array}{c}\text { Big } \\
\text { Classification } \\
(\mathrm{BC}) \\
\end{array}$ & \multicolumn{2}{|l|}{ Medium Classification(MC) } \\
\hline \multirow{3}{*}{$\begin{array}{c}\text { Terminal \& } \\
\text { Component, } \\
\text { Testing/Certificati } \\
\text { on (A) }\end{array}$} & Convergence Terminal & $\mathrm{AA}$ \\
\hline & Convergence Component & $\mathrm{AB}$ \\
\hline & $\begin{array}{c}\text { Mobile Communication } \\
\text { Testing/Certification System }\end{array}$ & $\mathrm{AC}$ \\
\hline \multirow{2}{*}{$\begin{array}{l}\text { Service Platform } \\
\text { (B) }\end{array}$} & Convergence Service Platform & $\mathrm{BA}$ \\
\hline & Platform Supporting Mobility & $\mathrm{BB}$ \\
\hline \multirow{3}{*}{$\begin{array}{c}\text { Mobile } \\
\text { Communication } \\
\text { Access System } \\
\text { (C) }\end{array}$} & $\begin{array}{c}\text { Broadband Mobile } \\
\text { Communication System }\end{array}$ & $\mathrm{CA}$ \\
\hline & $\begin{array}{l}\text { Near Field Communication } \\
\text { System }\end{array}$ & $\mathrm{CB}$ \\
\hline & $\begin{array}{l}\text { Mobile Communication } \\
\text { Application System }\end{array}$ & $\mathrm{CC}$ \\
\hline
\end{tabular}

Source: Korean Industrial technology roadmap 2011, KIAT, 2012 
As a first step for understanding the technology capabilities of competitors, patent activity (PA) analysis was performed. In the patent activity analysis, the first step analyze an investigated ratio of the latest technologies to the relevant technical field.

NARIN [12] calculated the effect of technological innovation outputs for the past five years in a current impact index (CII) on the present point. The $\mathrm{CII}$ is obtained by the formula stated below:

$$
C I I=\frac{\sum_{i=1}^{n}\left(A C_{i} \times A R_{i}\right)}{\sum_{i=1}^{n} A R_{i}}
$$

( $i$ : Before $\mathrm{n}$ years at current year, $A C_{i}$ : Citation ratio of the company $[\mathrm{A}]$ in year I,

$A R_{i}$ : Number of patents of the company $[\mathrm{A}]$ in year i)
(a) $R C_{i}=\frac{C I_{i}}{R_{i}}$
(b) $A R C_{i}=\frac{A C I_{i}}{A R_{i}}$

(c) $A C_{i}=\frac{A R C_{i}}{R C_{i}}$

( $R C_{i}$ : Average cites per patent in year I,

$C I_{i} \quad$ :Number of citation in year I,

$R_{i}$ :Number of patents in year I,

$A R C_{i}: R C_{i}$ of the company [A],

$A C I_{i}: C I_{i}$ of the company[A],

$A R_{i}: R_{i}$ of the company [A])

A ratio of the latest patents is calculated by a ratio of the number of applications filed after 2006 among patents targeted for analysis, and indexes the technology development trend in the relevant field.

A ratio of the latest patents (RLP) is represented by the following formula.

$$
R L P=\frac{N P(l s t f)}{N P(t f)}
$$

(Analysis after 2006 for the latest section)

RLP: Ratio of Latest Patents / NP(1stf): Number of Patents of latest section in Technological field / NP(tf):
Number of Patents in Technological field

In the patent activity analysis, the second step analyze an investigated ratio of triad patent families invested in the relevant technical field.

The ratio of triad patent families is defined as a ratio of patents, which were filed in main countries having high importance in light of the preoccupancy of technologies and the securing of markets, to the targeted patents for analysis. Here, the triad patent families are based on patents simultaneously filed in the USPTO, Japanese Patent Office and European Patent Office.

DERNIS and KHAN [4] evaluated a difference in comparative analysis data among triad patent families. The share of patents for each country is influenced by rules and regulations of the Patent Offices and patent strategies. Accordingly, the calculation of triad patent families provides an indicator for measuring the innovation outcomes of countries.

The share of patents for each country is presented in Fig. 1. Fig. 1 shows a comparison of nationalities of applicants for patents filed in comparative countries. Here, the $\mathrm{X}$-axis shows the comparative countries, and the $\mathrm{Y}$-axis shows a ratio (\%) of nationalities of the applicants for each country. As shown in the figure, the EPO or the USPTO shows that the occupation ratio of applications filed by their country persons is high, but shows that triad patent families have a small difference in occupation ratio among applicants for each country. Accordingly, objective statistic results could be obtained through analysis based on the triad patent families.

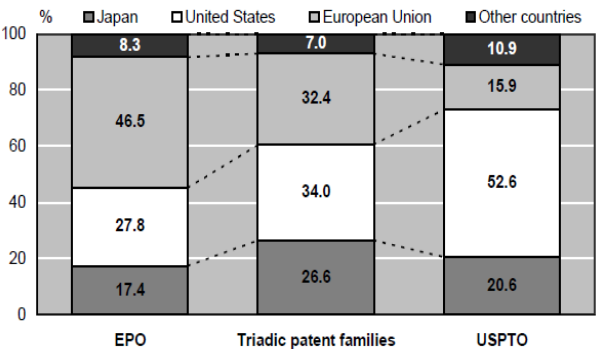

Source: Triadic patent families methodology, OECD Publishing, 2004. [Fig. 1] Country shares of patents applied for at the EPO, USPTO, and TPF 
A ratio of triad patent families (RTPF) is represented by the following formula:

$$
R T P F=\frac{N P T P F(t f)}{N P(t f)}
$$

RTPF: Ratio of Triad Patent Families / NPTPF(tf): Number of Patents of Triad Patent Families in Technological field / NP(tf): Number of Patents in Technological field

As the second step for understanding the technology capabilities of competitors, technological independence (TI) analysis was performed. In the technological independence analysis, the first step shows a monopoly indicator (MI).

The monopoly indicator (MI) is an indicator used for evaluating the monopoly situations of markets and competitive strength and is calculated using the share of patent applications instead of a market share. It means that the nearer a value of the monopoly indication (MI) is to zero, the more technological innovation activities are dispersed into various companies. [10]

The monopoly indicator (MI) is represented by the following formula.

$$
M I=\sum_{i=1}^{m} S_{i}^{2}=\sum_{i=1}^{m}\left(\frac{N_{i}}{N} \times 100\right)^{2}
$$

( $S_{i}$ :Share of Patents of the company [i], m: Number of companies in Technological field,

$N_{i}$ : Number of patents of the company [i],

$N$ : Number of patents in whole field)

In the technological independence analysis, the second step shows a dependence ratio of domestic technology (DRDT).

The DRDT is an indicator for checking a level of technology protection of local residents by comparing the number of patent applications filed by each of the local residents and foreigners together. It means that as the DRDT is gradually increased, the occupation ratio of the patent applications filed by foreigners is high compared to that of the patent applications filed by local residents. That is, it means that as the value of the DRDT comes gradually nearer to Zero, the share of technologies of local residents is higher. [11]

The dependence ratio of domestic technology (DRDT) is represented by the following formula:

$$
D R D T=\frac{N P F(t f)}{N P L(t f)}
$$

DRDT: Ratio Dependence Ratio of Domestic Technology / NPF(tf): Number of Patents of Foreigners in Technological field / NPL(tf): Number of Patents of Locals in Technological field

As a last step for assessing the technology capabilities of competitors, technology portfolio (TP) analysis was performed. In the TP analysis, main applicants selected through the evaluation of Step 1 are matched with the technology classifications selected through the evaluation of Step 2. Furthermore, a technology scope showing a relatively high occupation ratio of applications in each applicant and technology classification was selected.

Table 2 below presents a score standard for each

\begin{tabular}{|c|c|}
\hline Step & Standard \\
\hline $\begin{array}{c}\text { Step1 } \\
\text { Patent Activity } \\
\text { (Top } \\
\text { Companies) } \\
\end{array}$ & $\begin{array}{l}\text { If Ratio of Latest Patents }(\%)>\text { Average, } \\
1 \text { Point, if not } 0 \text { Point } \\
\text { If Ratio of Triad Patent Families }(\%)> \\
\text { Average, } 1 \text { Point, if not } 0 \text { Point }\end{array}$ \\
\hline $\begin{array}{l}\quad \text { Step2 } \\
\text { Technological } \\
\text { Independence }\end{array}$ & $\begin{array}{c}\text { If Monopoly Indicator > Average, } 1 \\
\text { Point if not } 0 \text { Point } \\
\text { If Dependence Ratio of Domestic } \\
\text { Technology }(\%)>\text { Average, } 1 \text { Point if not } \\
0 \text { Point }\end{array}$ \\
\hline $\begin{array}{l}\text { Step3 } \\
\text { Technology } \\
\text { Portfolio } \\
\text { (Main } \\
\text { Companies) } \\
\end{array}$ & $\begin{array}{c}\text { Ratio of technical fields of main } \\
\text { Applicants }(\%)>\text { Average } \\
\text { Technology portfolio ratio of main } \\
\text { Applicants }(\%)>\text { Average }\end{array}$ \\
\hline
\end{tabular}
step.

〈Table 2〉 Score Standard for Each Step 


\section{Analysis Results}

As the first step for technology capability analysis of competitors, the RLP and RTPF regarding the top 16 companies in the number of applications were compared with each other. As a result, each company showing a RLP and RTPF which is higher than average was provided with 1 point, so 9 companies provided with at least 1 point were selected.

Fig. 2 below shows a distribution chart for the RLP and RTPF of the top 16 companies. Here, each size of bubbles shows the number of patents of companies.

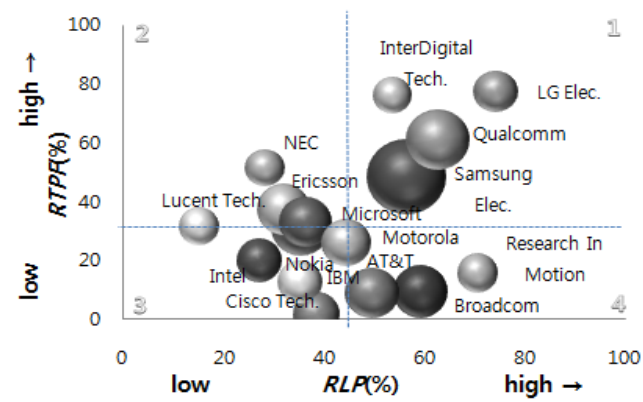

RLP: Ratio of Latest Patents (\%)

RTPF: Ratio of Triad Patent Families (\%)

[Fig. 2] Patent Activity Analysis of Top Companies

$<$ Table 3> below shows RLP and RTPF analysis of the top 16 companies in the number of applications based on the analysis in Step 1.

Companies showing an above-average RLP and RTPF among a total of 16 companies are 9 companies, such as Samsung Elect, Qualcomm, Broadcom, AT\&T, Ericsson, LG Elect, Research in Motion, InterDigital Tech, and NEC.

〈Table 3〉 Analysis Indicators of Patent Activity

\begin{tabular}{|c|c|c|c|}
\hline \multicolumn{2}{|c|}{9 companies selected } & \multicolumn{2}{|c|}{$\begin{array}{l}\text { Step1 } \\
\text { among the top } 16 \text { Companies }\end{array}$} \\
\hline Applicant & RLP & RTPF & Score \\
\hline Company A & 56.61 & 48.14 & 2 \\
\hline Company B & 62.76 & 60.69 & 2 \\
\hline Company C & 35.64 & 31.03 & 0 \\
\hline Company D & 59.40 & 8.96 & 1 \\
\hline Company E & 49.68 & 8.60 & 1 \\
\hline Company F & 32.13 & 37.05 & 1 \\
\hline
\end{tabular}

\begin{tabular}{c|c|c|c}
\hline Company G & 36.49 & 32.77 & 0 \\
\hline Company H & 44.74 & 25.94 & 0 \\
\hline Company I & 38.66 & 1.26 & 0 \\
\hline Company J & 27.31 & 19.82 & 0 \\
\hline Company K & 74.30 & 77.10 & 2 \\
\hline Company L & 35.41 & 12.44 & 0 \\
\hline Company M & 70.72 & 15.47 & 1 \\
\hline Company N & 15.38 & 31.36 & 0 \\
\hline Company O & 53.70 & 75.93 & 2 \\
\hline Company P & 28.40 & 51.23 & 1 \\
\hline Average & 45.08 & 33.61 & 0 \\
\hline
\end{tabular}

RLP: Ratio of Latest Patents(\%)

RTPF: Ratio of Triad Patent Families(\%)

In the second step for analyzing the technology capabilities of competitors, the MI and the DRDT regarding the technology classification of mobile communication were compared to each other.

As a result of this, when the MI and DRDT are higher than the average of each technology classification, each of them was provided with 1 point. Thus, a total of five technologies provided with at least 1 point were selected.

Fig. 3 below shows a distribution chart of the MI and DRDT for a total of eight technology classifications. Here, each size of the bubbles shows the number of patents relating to a relevant technology.

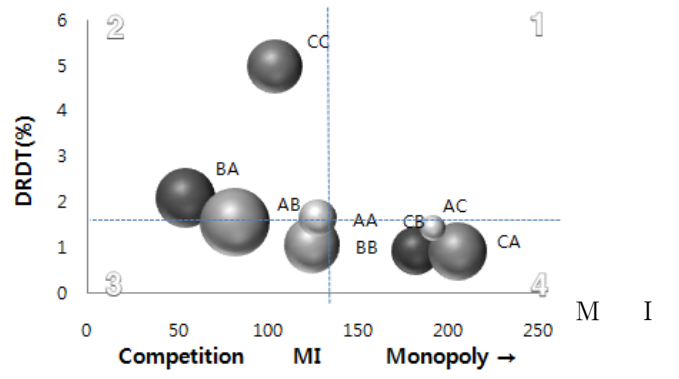

Monopoly Indicator

DRDT: Dependence Ratio of Domestic Technology(\%)

[Fig. 3] Technological Independence Analysis of Technology Classification

Table 4 below shows results of selecting five technologies from eight medium technology classifications by Step 2.

In the total of eight technology classifications, five classifications, such as $\mathrm{AC}, \mathrm{BA}, \mathrm{CA}, \mathrm{CB}$, and $\mathrm{CC}$ were 
selected as technologies showing an above-average MI and DRDT.

$\langle$ Table 4〉 Analysis Indicators of Technological Independence

\begin{tabular}{c|c|c|c}
\hline \multicolumn{4}{c}{$\begin{array}{c}\text { Step2 } \\
\text { selected among the } 8 \text { medium } \\
\text { classifications. }\end{array}$} \\
\hline Classification & MI & DRDT & Score \\
\hline AA & 127.65 & 1.64 & 0 \\
\hline AB & 81.74 & 1.54 & 0 \\
\hline AC & 191.30 & 1.41 & 1 \\
\hline BA & 54.54 & 2.07 & 1 \\
\hline BB & 124.59 & 1.03 & 0 \\
\hline CA & 205.24 & 0.90 & 1 \\
\hline CB & 181.90 & 0.91 & 1 \\
\hline CC & 104.18 & 4.96 & 1 \\
\hline Average & 133.89 & 1.81 & - \\
\hline
\end{tabular}

MI: Monopoly Indicator

DRDT: Dependence Ratio of Domestic Technology (\%)

The last step for assessing the technology capabilities of competitors is as follows.

The nine main companies selected through the patent activity (PA) analysis of Step 1 were disposed. The five technology classifications selected through technological independence (TC) analysis of Step 2 were matched with the nine main companies. Furthermore, items showing an above-average ratio of applications in number were selected from the five technology classifications.

Consequently, as shown in Table 5, technology portfolio analysis showing research fields focused by each company was completed.

\section{〈Table 5〉 Analysis Indicators of Technology Portfolios}

Step3

\begin{tabular}{c|c|c|c|c|c|c|c|c|c}
\hline Applicant & N/P & AA & AB & AC & BA & BB & CA & CB & CC \\
\hline Company A & 713 & 6.73 & 18.79 & 2.81 & 4.91 & 15.57 & 26.09 & 23.14 & 1.96 \\
\hline Company B & 455 & 1.32 & 29.23 & 0.88 & 3.96 & 6.15 & 28.57 & 9.23 & 20.66 \\
\hline Company D & 361 & 1.39 & 25.48 & 1.94 & 9.14 & 3.05 & 31.58 & 18.56 & 8.86 \\
\hline Company E & 341 & 2.93 & 22.29 & 0.29 & 24.63 & 13.20 & 7.04 & 13.78 & 15.84 \\
\hline Company F & 324 & 4.01 & 21.30 & 3.09 & 6.79 & 23.15 & 30.86 & 4.32 & 6.48 \\
\hline Company K & 236 & 0.85 & 14.83 & 9.32 & 2.97 & 5.51 & 58.05 & 5.51 & 2.97 \\
\hline Company M & 193 & 1.55 & 25.91 & 1.04 & 5.70 & 28.50 & 13.47 & 13.99 & 9.84 \\
\hline Company O & 190 & 1.58 & 5.79 & 11.05 & 2.11 & 1.58 & 41.58 & 23.16 & 13.16 \\
\hline Company P & 165 & 1.82 & 14.55 & 1.21 & 10.91 & 23.64 & 23.03 & 20.61 & 4.24 \\
\hline \multicolumn{1}{c|}{ Average } & 2.46 & 19.80 & 3.51 & 7.90 & 13.37 & 28.92 & 14.70 & 9.34 \\
\hline N/P: Number of Patent in Main Applicant
\end{tabular}

$\mathrm{AA}^{\sim} \mathrm{CC}$ : Filed Ratio of Technology Classification (\%)

Among the top 16 companies in the number of applications in the field of next generation mobile communication derived through the analysis processes as shown in Fig. 2, Fig. 3, Table 3, Table 4, Table 5 above, the nine companies passing through Step 1 were selected. As technical fields passing through Step 2, five technical fields of a total of eight medium classifications were selected. Consequently, the focused technical fields of the leading companies finally selected in Step 3 were selected.

Table 6 below shows the technology portfolios of leading companies.

\begin{tabular}{|c|c|c|c|c|c|c|c|c|}
\hline \multirow{2}{*}{$\begin{array}{c}\text { Main } \\
\text { Applicants }\end{array}$} & \multicolumn{4}{|c|}{ Medium } & \multicolumn{4}{|c|}{ assification $(\mathrm{MC})$} \\
\hline & $\mathrm{AA}$ & $\mathrm{AB}$ & $\mathrm{AC}$ & $\mathrm{BA}$ & $\mathrm{BB}$ & $\mathrm{CA}$ & $\mathrm{CB}$ & $\mathrm{CC}$ \\
\hline Company A & & & & & & & V & \\
\hline Company B & & & & & & & & $\sqrt{ }$ \\
\hline Company D & & & & $\sqrt{ }$ & & $\sqrt{ }$ & $\sqrt{ }$ & \\
\hline Company E & & & & $\sqrt{ }$ & & & & $\sqrt{ }$ \\
\hline Company $\mathrm{F}$ & & & & & & $\sqrt{ }$ & & \\
\hline Company K & & & $\sqrt{ }$ & & & $\sqrt{ }$ & & \\
\hline Company M & & & & & & & & $\sqrt{ }$ \\
\hline Company $\mathrm{O}$ & & & $\sqrt{ }$ & & & $\sqrt{ }$ & $\sqrt{ }$ & $\sqrt{ }$ \\
\hline Company $\mathrm{P}$ & & & & $\sqrt{ }$ & & & $\sqrt{ }$ & \\
\hline
\end{tabular}

\section{Conclusion}

Patent statistic analysis and patent indicator analysis of various methods for effective R\&D management of each company have been usefully utilized as methods for objectively evaluating the technological capabilities of competitors. The technological capability analysis of competitors was carried out step by step as follows.

In the first step, the top 16 companies in the number of applications were selected and thus patent activity (PA) analysis was carried out. As a result of the analysis, nine main companies were selected.

In the second step, technology independence (TI) analysis for a total of eight technology classifications was carried out. As a result of the analysis, five 
technology classifications having excellent competitiveness were selected.

In the third step, by matching the main companies selected in each step and the technology classifications having excellent competitiveness selected in each step with each other, technology portfolio analysis for selecting the scopes showing an above-average occupation ratio of applications was carried out. As a result of the analysis, 17 technology classifications from a total of nine companies were selected as the scope of the main technology portfolio.

In this paper, could be confirmed each competitors technology portfolio. Therefore, needs to establishment of R\&D strategy refer to each competitor's technology portfolio. It is expected that the method presented through the technological capability analysis of competitors will have a large influence on strategic R\&D management of each company. especially through such a analysis, portfolios for important technologies which have been concentrically researched by competitors could be analyzed. Also, the present analysis results will help to implement strategic $R \& D$ management, such as the establishment of company $\mathrm{R} \& \mathrm{D}$ plans.

The limitation of this study is recent data about the mobile communication technology has not been reflected. In addition, Companies needs to objective methodology for the R\&D management. It is important for the R\&D management of companies to have an objective and reasonable methodology for making decisions. Accordingly, continuous research is needed for methodological development from which more detailed and objective results can be obtained in the future. In addition to the information for the analysis should be updated with the latest patent information.

\section{Acknowledgement}

This research was financially supported by Hansung University.

\section{REFERENCES}

[1] BAGLIERI, Daniela; CESARONI, Fabrizio. Capturing the real value of patent analysis for $R \& D$ strategies. Technology Analysis \& Strategic Management, 25.8: 971-986, 2013.

[2] CHIU, Yu-Jing; CHEN, Yuh-Wen. Using AHP in patent valuation. Mathematical and Computer Modelling, 46.7: 1054-1062, 2007.

[3] Daim T. U., Rueda G., Martin H., Gerdsri P, Forecasting emerging technologies: use of bibliometrics and patent analysis. Technological Forecasting and Social Change, 73(8): 981-1012, 2006.

[4] Dernis, H., Khan M. Triadic patent families methodology. OECD Publishing, 2004.

[5] ÉRDI, Péter, et al. Prediction of emerging technologies based on analysis of the US patent citation network. Scientometrics, 1-18, 2013.

[6] ERNST, Holger. Patent information for strategic technology management. World Patent Information, 25.3: 233-242, 2003.

[7] ERNST, Holger. Patent portfolios for strategic R\&D planning. Journal of Engineering and Technology Management, 15.4: 279-308, 1998.

[8] GAO, Lidan, et al. Technology life cycle analysis method based on patent documents. Technological Forecasting and Social Change, 2012.

[9] KIAT. Industrial technology roadmap 2011-next generation mobile communication, KIAT, 2012.

[10] KIPI, Patent analysis methodology for making of technology roadmap. Korea Institute of Patent Information, 2005.

[11] KIPO, Development of Indicators for IP Competitiveness and Characteristics, KIPO /KIIP, 2012.

[12] NARIN, Francis. Tech-line background paper. CHI Research, Inc., Haddon Heights, NJ, downloadable at www.chiresearch. com, 2000.

[13] SHIH, Meng-Jung; LIU, Duen-Ren; HSU, Ming-Li. Discovering competitive intelligence by 
mining changes in patent trends. Expert Systems with Applications, 37.4: 2882-2890, 2010.

[14] TRAPPEY, Amy JC, et al. A patent quality analysis for innovative technology and product development. Advanced Engineering Informatics, 26.1: 26-34, 2012.

[15] Tseng Fang-mei, HSIEH Chih-hung, PENG Ya-ni, CHU Yi-wei. Using patent data to analyze trends and the technological strategies of the amorphous silicon thin-film solar cell industry. Technological Forecasting and Social Change, 78(2): 332-345, 2011.

[16] WILSON, R. M. Patent analysis using online databases - I. Technological trend analysis. World Patent Information, 9.1: 18-26, 1987.

[17] XU, G. Gann. Information for corporate IP management. World Patent Information, 26.2: 149-156, 2004.

[18] ZHENG, Jia, et al. Influences of counting methods on country rankings: a perspective from patent analysis. Scientometrics, 1-16, 2013.

\section{Choi, Seung Wook(최 승 욱)}

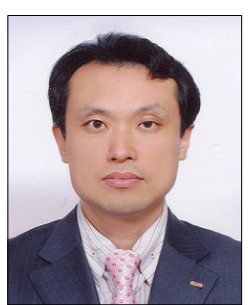

• Feb. 1993 : Hanyang Univ. Mechanical Engineering (Engineering Bachelor's Degree) Feb. 2011 : Hansung Univ. Consulting(Master's Degree)

- Mar. $2012 \sim$ Current : Hansung Univ. Doctoral Student, Dept. Of Knowledge Service \& Consulting

- Jul 1994 Aug. 1999 : Daewoo Electronics Co. Ltd / Dept. of Intellectual Property

- Aug 1999 Current : WIPS Co. Ltd / Managing Director

- Interesting Field: Technology Strategy, Technology Forecasting, R\&D Management, Patent indicators

•E-Mail : boying1177@gmail.com
Lee, Chang Won(이 창 원)

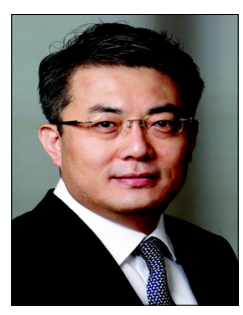

Aug. 1986 : Graduate School of Business Administration, Yonsei Univerisy, Seoul, Korea (Master's Degree).

- Dec. 1991 : Majored in Organizational Studies, State University of New York at Albany (Ph.D. in Organizational Studies).

- Aug. $1992 \sim$ Current : Professor, Department of Public Administration, Hansung Unviersity

- Jan. $2007 \sim$ Dec. 2007 : President, Korean Association for Policy Sciences

- Jan. 2008 Dec. 2008 : President, Korean Association for Organizational Studies

- Jun. $2012 \sim$ Feb. 2014 : Head, Research Institute for Government Reforms

- Interesting Field: Organization, Government Reform, Public Policy, Technology Policy, Administration, Technology Forecasting, Patent indicators, Consulting (Strategy)

·E-Mail : chang717@hansung.ac.kr

You, Yen Yoo(유 연 우)

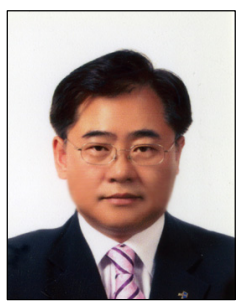

- Aug. 1996 : Graduate School of Information Sciences SoongSil University, Seoul Korea(Master's Degree)

- Feb. 2007 : Major in Public Administration Department of Public Administration Graduate School of Hansung University(doctor's degree)

- Feb. $2002 \sim$ Apr. 2009 : Korea Technology and Information Promotion Agenccy for SMEs

- Sep. $2008 \sim$ Current : Professor, Dept. of Knowledge Service of Consulting, Hansung University, Seoul Korea - Interesting field : Consulting(Strategy, Project Management, Performance Management, MOT), CSR, Technology Innovation, Management Innovation, Service R\&D, Franchise, Intellectual property

·E-Mail : threey0818@hansung.ac.kr 